World Lumen Congress 2021 | May 26-30, 2021 |

lasi, Romania

\title{
Correlations between Agility, Speed and Effort Capacity in Women's Soccer, Handball and Rugby
}

\author{
Florin NICHIFOR, Petruț-Florin TROFIN, \\ Florentina-Petruţa MARTINAŞ
} https://doi.org/10.18662/wlc2021/52

How to cite: Nichifor, F., Trofin, P.-F., \& Martinaş, F.-P. (2021). Correlations between Agility, Speed and Effort Capacity in Women's Soccer, Handball and Rugby. In A. Sandu (vol. ed.), Lumen Proceedings: Vol. 17 World Lumen Congress 2021 (pp. 514-520). Iasi, Romania: LUMEN Publishing House. https://doi.org/10.18662/wlc2021/52 


\title{
Correlations between Agility, Speed and Effort Capacity in Women's Soccer, Handball and Rugby
}

\author{
Florin NICHIFOR ${ }^{1}$, Petruț-Florin TROFIN², \\ Florentina-Petruța MARTINAŞ3
}

\begin{abstract}
In team sports, the essential factors in achieving performance are represented by speed and agility, expressed in conditions of high intensity and high volume. The aim of this study is to analyze the relationships between speed, agility and effort in women's soccer, rugby and handball. At the same time, we want to compare these parameters in order to determine the profile for each discipline. The research analyzed 49 performance women atbletes from the first leagues of Romania, divided into 3 groups: soccer, rugby and handball. To evaluate the speed we applied the $10 \mathrm{~m}$ test. Agility was assessed using samples 505 and 1001. Anaerobic effort capacity was assessed by the $8 \times 10+$ $10 \mathrm{~m}$ and aerobic effort capacity by the VAM-Eval test. The Pearson correlation showed a direct relationship between 505 and 1001, for all groups. Significant correlations were shown between speed and agility, the effort capacity being also involved in the detected interferences.
\end{abstract}

Keywords: performance; effort capacity; speed; team sports; agility.

\section{Introduction}

In many team sports like basketball, football and rugby, elite versus sub-elite athletes are characterized by balance, linear sprint, muscle strength, power and reactive change of direction performances (Asadi et al., 2017; Makhlouf et. al., 2018).

In the game of rugby, the relationship between fitness and physical characteristics in relation to game statistics is considered important for success in which body composition, speed, strength and sprint ability, are

$1 \mathrm{PhD}$, Lecturer, "Alexandru Ioan Cuza" University" of Iaşi, România, florinnichifor71@yahoo.com

${ }^{2} \mathrm{PhD}$, Lecturer, "Alexandru Ioan Cuza" University" of Iaşi, România, trofin.florin@,uaic.ro

3 Assist. doctoral, "Alexandru Ioan Cuza" University" of Iaşi, România, petruta.martinas@uaic.ro 
important factors in the sport performance (Smart et al., 2014). Rugby is a high-intensity sport that is popular globally (Lindsay et al., 2015).

This high-intensity activities such as sprinting, jumping or changing directions are the most common actions in sports games, like soccer or rugby, encountered during matches (Bloomfield et al., 2007).

Thus, the link between speed and agility in the game of football was investigated, finding correlations between 40 yard dash and 20 yard shuttle times, but there were also authors who denied this statement (Spaniol et al., 2010).

One of the most important actions encountered in sports games is the change of direction, which can influence the outcome of a match through rapid changes in game phases or rapid changes in speed (Nimphius et al., 2018). Previous studies have shown that different speed qualities (Pereira et al., 2018; Freitas et al., 2019a; Freitas et al., 2019b Loturco et al., 2019;) are positively associated with superior change of direction ability, as faster players in linear trajectories are usually faster when changing direction.

Specialists investigating the biological potential of high-performance athletes have concluded that among football, rugby and handball players, athletes who perform better in sprint events do not get significant results in assessing change of direction (Loturco et al., 2018; Freitas et al., 2018, 2019; Pereira et al., 2018).

\section{Methods}

The research aims to analyze the links that may exist between speed, agility and effort capacity, both anaerobic and aerobic. The analysis is made of players from Romania's first value divisions in football, handball and rugby.

The 49 professional players were divided into 3 groups, depending on the discipline practiced: football $(\mathrm{N}=15,20.19 \pm 4.26$ years, $57.21 \pm 8.83$ $\mathrm{kg}, 28.77 \pm 2.28 \%$ muscle mass, $30.17 \pm 4,45 \%$ body fat), handball $(\mathrm{N}=15$, $28.06 \pm 3.99$ years, $71.11 \pm 8.27 \mathrm{~kg}, 30.94 \pm 1.31 \%$ muscle mass, $29.21 \pm$ $2.45 \%$ body fat $)$ and rugby $(\mathrm{N}=19,18,57 \pm 3.43$ years, $58.52 \pm 5.04 \mathrm{~kg}$, $31.62 \pm 3.29 \%$ muscle mass, $28.31 \pm 5.35 \%$ body fat).

We used the following physical tests: $10 \mathrm{~m}$ sprint, 505, 1001, $8 \times 10+10 \mathrm{~m}$ and VamEval. The results were collected and then analyzed using GraphPad Prism 6 software. 


\section{Results}

Data processing led to their synthesis in the form of the results in Tables 1-4. The results of the 5 samples are expressed as the mean and standard deviation (Table 1).

Table 1. Results of applied physical tests. Author's own conception

\begin{tabular}{lllll}
\hline & $\begin{array}{l}\text { Football } \\
\mathrm{n}=15\end{array}$ & $\begin{array}{l}\text { Handball } \\
\mathrm{n}=15\end{array}$ & $\begin{array}{l}\text { Rugby } \\
\mathrm{n}=19\end{array}$ & $\mathrm{p}$ \\
\hline $10 \mathrm{~m}(\mathrm{~s})$ & $2.11 \pm 0.14$ & $2.07 \pm 0.37$ & $2.05 \pm 0.18$ & 0,80 \\
$505(\mathrm{~s})$ & $2.71 \pm 0.12$ & $2.63 \pm 0.17$ & $2.69 \pm 0.42$ & 0,71 \\
$1001(\mathrm{~s})$ & $4.53 \pm 0.18$ & $4.40 \pm 0.23$ & $4.31 \pm 1.14$ & 0,67 \\
$\mathrm{D} \%$ & $6.28 \pm 2.42$ & $6.89 \pm 5,16$ & $6.12 \pm 1.92$ & 0,79 \\
$\mathrm{vO} 2 \mathrm{max}(\mathrm{ml} / \mathrm{kg} / \mathrm{min})$ & $47.27 \pm 3.64$ & $50.18 \pm 4.44$ & $48.83 \pm 6.23$ & 0,32 \\
\hline
\end{tabular}

In the physical tests, the statistical differences between the three categories of sportswomen are negligible, as evidenced by the value of the significance threshold calculated in the Anova test (p). Thus, we cannot speak of a clear detachment of a type of sportswoman, from a physical point of view.

The $10 \mathrm{~m}$ test shows an average and a good homogenization for rugby players $(2.05 \pm 0.18 \mathrm{~s})$, the scattering of values being higher for the handball team $(2.07 \pm 0.37 \mathrm{~s})$.

The agility of football, handball and rugby players is close in value to both tests used. At test 505, handball players recorded a better average and spread $(2.63 \pm 0.17 \mathrm{~s})$, and at 1001 rugby players $(4.31 \pm 1.14 \mathrm{~s})$. It seems that in agility, the average values of football players are the weakest.

The lower the $\mathrm{D} \%$ values, the greater the ability to maintain maximum effort for longer periods of time. Our research showed that rugby players have a better average and homogeneity of results $(6.12 \pm 1.92)$, the opposite pole being occupied by handball (6.89 \pm 5.16$)$.

Maximum oxygen consumption, an accurate indicator of aerobic exercise capacity, highlights handball players $(50.18 \pm 4.44 \mathrm{ml} / \mathrm{kg} / \mathrm{min})$.

Next, we focused on the interrelationships that are established within the groups at the level of the presented results.

Between the results of the tests applied to the football players to establish 3 correlations: $1001-10 \mathrm{~m}(\mathrm{r}=0.68, \mathrm{p}=0.004), 1001-505(\mathrm{r}=0.81$, $\mathrm{p}=0.0002)$ and $\mathrm{vO} 2 \mathrm{max}-\mathrm{D} \%(\mathrm{r}=-0.58, \mathrm{p}=0.03)$. Thus, the agility and speed tests are in direct interconnection, as are the two effort capacities (Table 2). 
Table 2. Correlations for the football group. Author's own conception

\begin{tabular}{lllll}
\hline & $\begin{array}{l}\text { F_10 } \\
(\mathrm{s})\end{array}$ & $\begin{array}{c}\mathrm{mF} \text { F_505 } \\
(\mathrm{s})\end{array}$ & $\begin{array}{l}\text { F_1001 } \\
(\mathrm{s})\end{array}$ & $\begin{array}{l}\text { F_D \% F_VO2max } \\
(\mathrm{ml} / \mathrm{kg} / \mathrm{min})\end{array}$ \\
\hline F_10 $(\mathrm{s})$ & & & & \\
F_505 $(\mathrm{s})$ & 0.44 & & & \\
F_1001 $(\mathrm{s})$ & $0.68^{* *}$ & $0.81^{* * *}$ & & \\
F_D\% & 0.29 & 0.18 & 0.32 & \\
F_VO2max $(\mathrm{ml} / \mathrm{kg} / \mathrm{min})$ & -0.12 & -0.26 & -0.09 & $-0.58^{*}$ \\
\hline
\end{tabular}

Handball players show a correlation between agility tests with a change of direction of running $(\mathrm{r}=0.70, \mathrm{p}=0.003)$, each of them also related to the result of the VamEval test $(505: \mathrm{r}=-0.57, \mathrm{p}=0.02 ; 1001: \mathrm{r}=-0.72$, $\mathrm{p}=0.002)$. There is also a negative correlation between 1001 and the test result $8 \times 10+10 \mathrm{~m}(\mathrm{r}=-0.65, \mathrm{p}=0.007)($ Table 3$)$.

Table 3. Correlations for the handball group. Author's own conception

\begin{tabular}{lcllll}
\hline & H_10 & H_505 & H_1001 & H_VO2max \\
& $\mathrm{m}(\mathrm{s})$ & $(\mathrm{s})$ & $(\mathrm{s})$ & H_D $\%$ & $(\mathrm{ml} / \mathrm{kg} / \mathrm{min})$ \\
\hline H_10 $\mathrm{m}(\mathrm{s})$ & & & & & \\
H_505 (s) & 0.19 & & & & \\
H_1001 (s) & 0.41 & $0.70^{* *}$ & & & \\
H_D $\%$ & -0.19 & -0.40 & $-0.65^{* *}$ & & \\
H_VO2max $(\mathrm{ml} / \mathrm{kg} / \mathrm{min})$ & -0.13 & $-0.57^{*}$ & $-0.72^{* *}$ & 0.39 & \\
\hline
\end{tabular}

In the rugby team there is a connection between the results of the 505 test and the speed of movement $(\mathrm{r}=0.69, \mathrm{p}=0.0009)$, respectively the anaerobic lactacid capacity $(\mathrm{r}=0.47, \mathrm{p}=0.04)$. In addition, the maximum oxygen consumption is in negative correlations with: $10 \mathrm{~m}(\mathrm{r}=-0.76$, $\mathrm{p}=0.0001), 505(\mathrm{r}=-0.79, \mathrm{p}=0.00008)$ and $8 \mathrm{x} 10+10 \mathrm{~m}(\mathrm{r}=-0.77, \mathrm{p}=0.0002)$ (Table 4).

Table 4. Correlations for the rugby team. Author's own conception

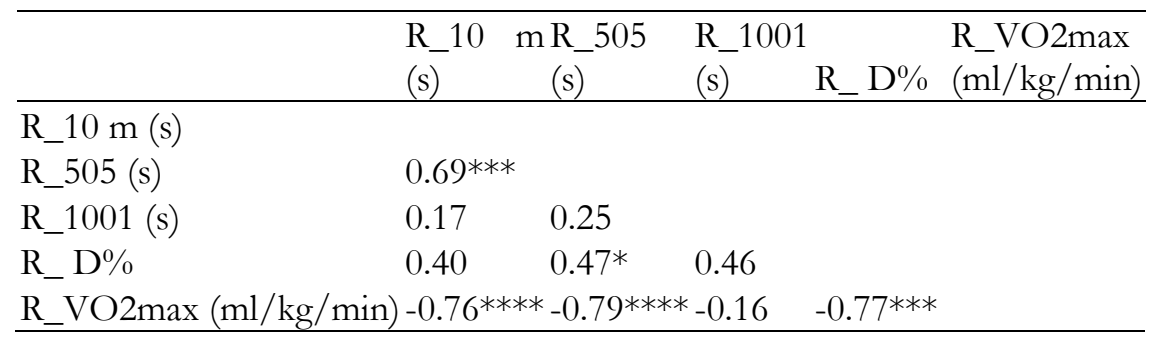




\section{Discussion}

For football players, the two agility tests are correlated with each other, which is normal, because the structure of the test is the same, the distances being different. In football, given the playing surface, changes in the direction of travel can be made both short and long distances. Travel speed is related to agility, but only to the results of test 1001. Therefore, improving the speed of release can lead to improved agility.

In handball, the results of the two agility tests are correlated in the same way as in football, only that the speed of movement is no longer involved in the correlation with them. Instead, there is a link between the data collected from test 1001 and those of $8 \times 10+10 \mathrm{~m}$, which can be explained by including the structure of the first in the second. Interesting is the link determined between the results of the agility tests and those of the VamEval test, so that they are interconditioned in value.

For rugby players, the speed of movement on $10 \mathrm{~m}$ is correlated with the agility on short distances, this being a specific feature of the game that in turn correlates with the anaerobic possibilities of the athletes. Aerobic exercise capacity is related to movement speed, agility and anaerobic capacity.

\section{Conclusion}

Travel speed, agility and the ability of anaerobic or aerobic effort are important components of the motor luggage needed for sports games. The sports disciplines in the women's level are gaining ground, being approached more and more seriously and with increasing implications of any nature. From the point of view of the motor potential, the professional football, handball and rugby players from Romania are close, there are no significant differences between them.

In football, the agility and speed of the athletes are connected, so their development in tandem is necessary to meet the requirements of the game.

Handball, taking place indoors and on the smallest surface of the three disciplines approached, implies the need for good agility, both for shorter and longer distances, hence the connection that is established between the results of the two profile tests used.

A contact sport, rugby requires players to have a good level of agility, which correlates with speed and anaerobic capacity. The connection between 
aerobic endurance and the other potential of sportswomen turns rugby into a complex discipline.

It would be interesting to analyze other parameters of physical effort in relation to the particularities of the sports studied, especially in girls, where the physiological characteristics are different from those of boys, who have been intensively studied.

\section{References}

Asadi, A., Arazi, H., Ramirez-Campillo, R., Moran, J., \& Izquierdo, M. (2017). Influence of maturation stage on agility performance gains after plyometric training: a systematic review and meta-analysis. Journal Strength Cond. Res, 31, 2609-2617. https://doi.org/10.1519/JSC.0000000000001994

Bloomfield, J., Polman, R., \& O'donoghue, P. (2007). Physical demands of different positions in FA Premier League soccer. Journal Sports Sci Med, 6, 63-70. https://www.ncbi.nlm.nih.gov/pmc/articles/PMC3778701/

Freitas, T. T., Alcaraz, P.E., Bishop, C., Calleja-González, J., Arruda, A.F.S., Guerriero, A., Reis, V.P., Pereira, L.A., \& Loturco, I. (2018). Change of Direction Deficit in National Team Rugby Union Players: Is There an Influence of Playing Position? Sports Basel, 7(1). https://doi.org/10.3390/sports7010002

Freitas, T. T., Alcaraz, P. E., Calleja-Gonzalez, J., Arruda, A.F.S., Guerriero, A, Kobal, R., Reis, V. P., Pereira, L. A., \& Loturco, I. (2019a). Differences in Change of Direction Speed and Deficit Between Male and Female National Rugby Sevens Players. Journal Strength Cond Res, 1. https://doi.org/10.1519/JSC.0000000000003195

Freitas, T. T., Pereira, L. A., Alcaraz, P. E., Arruda, A. F. S., Guerriero, A., Azevedo, P. H. S. M., \& Loturco, I. (2019b). Influence of Strength and Power Capacity on Change of Direction Speed and Deficit in Elite TeamSport Athletes. Journal of Human Kinetics, 68, 167-176. https://doi.org/10.2478/hukin-2019-0069

Lindsay, A., Draper, N., Lewis, J., Gieseg, S.P., \& Gill, N. (2015). Positional demands of professional rugby. Eur Journal Sport Science, 15, 480-487. https://doi.org/10.1080/17461391.2015.1025858

Loturco, I., Nimphius, S., Kobal, R., Bottino, A., Zanetti, V., Pereira, L.A., \& Jeffreys, I. (2018). Change-of direction deficit in elite young soccer players. German Journal Exerc Sport Res, 48, 228-234. https://doi.org/10.1007/s12662-018-0502-7

Loturco, I., Pereira, L.A., Freitas, T.T., Alcaraz, P.E., Zanetti, V., Bishop, C., \& Jeffreys, I. (2019). Maximum acceleration performance of professional soccer players in linear sprints: Is there a direct connection with changeof- 
direction ability?. PLoS One, 14(5).

https://doi.org/10.1371/journal.pone.0216806

Makhlouf, I., Chaouachi, A., Chaouachi, M., Ben Othman, A., Granacher, U., \& Behm, D.G. (2018). Combination of Agility and Plyometric Training Provides Similar Training Benefits as Combined Balance and Plyometric Training in Young Soccer Players. Front. Physiol, 9. https://doi.org/10.3389/fphys.2018.01611

Nimphius, S., Callaghan, S.J., Bezodis, N.E., \& Lockie, R.G. (2018). Change of Direction and Agility Tests: Challenging Our Current Measures of Performance. Strength Cond Journal, 40. 26-38. $\underline{10.1519 / \text { SSC.0000000000000309 }}$

Pereira, L.A., Nimphius, S., Kobal, R., Kitamura, K., Turisco, L., Orsi, R.C., Abad, C.C.C., \& Loturco, I. (2018). Relationship between change of direction, speed, and power in male and female National Olympic team handball athletes. Journal Strength Cond Res, 32(10), 2987-2994. https://doi.org/10.1519/JSC.0000000000002494

Smart, D., Hopkins, W.G., Quarrie, K.L., \& Gill, N. (2014). The relationship between physical fitness and game behaviours in rugby union players. Eur Journal Sport Science, 14. https://doi.org/10.1080/17461391.2011.635812

Spaniol, F., Flores, J., Bonnette, R., Melrose, D., \& Ocker, L. (2010). The relationship between speed and agility of professional arena league football players. Journal of Strength and Conditioning Research, 24(1). 10.1097/01.JSC.0000367217.41032.6c 